\title{
Passive Daylighting Design Strategies of Colonial Mosques in Malaysia
}

\author{
Aliyah Nur Zafirah Sanusi ${ }^{1}$, Ahmad Faisal Abdul Jamil1', Fadzidah Abdullah¹, Rosniza Othman² \\ 1 Department of Architecture, Kulliyyah of Architecture and Environmental Design, International Islamic University \\ Malaysia, Selangor, Malaysia, ${ }^{2}$ Faculty of Engineering, Prince Mugrin bin Abdulaziz University, Saudi Arabia
}

\begin{abstract}
This study aims to investigate the daylight performance of Colonial Mosques in Malaysia. The first objective of this study is to identify passive daylighting strategies from colonial mosques. The second objective of this study is to evaluate the daylight performance of the colonial mosques. The research methodology consisted of table research, field observation, and daylight analysis simulation of the prayer hall in the Colonial Mosques, using Sefaira daylighting simulation software. The results have shown that the daylight in Colonial Mosques was affected by the building orientation, shading elements, window to wall ratio, and window type. In conclusion, the clerestory window type enhances indoor daylight performance.
\end{abstract}

Keywords: Passive Daylighting, Colonial Mosques.

eISSN: 2398-4287@ 2021. The Authors. Published for AMER ABRA cE-Bs by e-International Publishing House, Ltd., UK. This is an open access article under the CC BYNC-ND license (http://creativecommons.org/licenses/by-nc-nd/4.0/). Peer-review under responsibility of AMER (Association of Malaysian Environment-Behaviour Researchers), ABRA (Association of Behavioural Researchers on Asians/Africans/Arabians) and cE-Bs (Centre for Environment-Behaviour Studies), Faculty of Architecture, Planning \& Surveying, Universiti Teknologi MARA, Malaysia.

DOI: https://doi.org/10.21834/ebpj.v6i17.2811

\subsection{Introduction}

A mosque is a place for Muslims to perform their congregational prayers, which needs optimum lighting for the occupiers to perform religious activities. However, the implementation of excessive artificial lighting in mosques may lead to additional costs for electrical energy consumption. Hence, using readily available daylighting is considered as one of the passive design strategies that should be implemented in mosque design (Malaysian Standard, 2014). Daylight can be part of renewable energy, that is free of charge (AlAshwal \& Hassan, 2017). Utilizing daylight is also part of zero-carbon emission buildings initiatives (Lo Verso \& Pellegrino, 2019). The use of natural daylight could reduce the electrical energy consumption for artificial lighting systems inside mosques.

Daylighting is a terminology to describe the utilization of natural light to illuminate the living space inside buildings (Heschong et al., 2002). As the sun is the primary source of light and energy to the earth, natural daylight is classified as a source of light distributed from direct and indirect sunlight. Nevertheless, the quality and intensity of daylight received at a certain region depend on the regional climate, sky condition, geographical latitude, and building geometry (Wong, 2017).

In Malaysia, most of the mosques are generally equipped with artificial lighting systems, especially at the main prayer halls which normally are located at the center of mosques. This is because the main prayer halls are usually designed with surrounded verandah areas, that leave the inner space of mosques lacking natural light casting. This typical layout of mosques requires the excessive use of artificial lighting, which may lead to very high energy consumption. A question arises on how the daylighting performance of mosques is. Hence, this research aims to investigate the daylight performance of colonial mosques in Malaysia; Ubudiah Royal Mosque, Pasir Pelangi Royal Mosque, and Sultan Ibrahim Jamek Mosque. These three colonial mosques were chosen to be investigated due to the

eISSN: 2398-4287@ 2021. The Authors. Published for AMER ABRA cE-Bs by e-International Publishing House, Ltd., UK. This is an open access article under the CC BYNC-ND license (http://creativecommons.org/licenses/by-nc-nd/4.0). Peer-review under responsibility of AMER (Association of Malaysian Environment-Behaviour Researchers), ABRA (Association of Behavioural Researchers on Asians/Africans/Arabians) and CE-Bs (Centre for Environment-Behaviour Studies), Faculty of Architecture, Planning \& Surveying, Universiti Teknologi MARA, Malaysia. 
similarity of their layout plans. The research has two (2) main objectives. The first objective is to identify the effective passive daylighting strategies from the selected colonial mosques, and the second objective is to evaluate the daylight performance of the main prayer halls in the colonial mosques.

As stated in a Quranic verse, "O children of Adam, take your adornment at every masjid, and eat and drink, but be not excessive. Indeed, He likes not those who commit excess" (Quran 7:31). Based on the verse, the Muslim communities must be aware of the responsibility towards the environment and self-awareness from being wasteful. Thus, excessive energy consumption is becoming an issue for mosques.

This study is aligned with the United Nations Agenda 2030 Sustainable Development Goals, SDG 7, 11, and 12. SDG 7 is Affordable Clean Energy which this study gave the solution in minimizing artificial lighting consumption and utilize natural daylight, which is more affordable and clean energy. SDG 11 is Sustainable Cities and Communities, which this study provided solutions in sustaining the operation of the mosques with natural resources rather than depending mostly on artificial resources. SDG 12 is Responsible Consumption and Production, where this study demonstrates the value of heritage buildings.

\subsection{Literature Review}

\subsection{Mosque Design}

The mosques in Malaysia are classified into three architectural styles. They are the vernacular mosque style, colonial mosque style, and modern mosque style (A Ghafar Ahmad, 1999). Rosniza (2011) came up with a list of Historical mosques: Traditional/vernacular and Colonials built between 1728 to 1956 and Post-Independence Mosques and Contemporary Mosques built from 1956 to 2005. Figure 1 shows the chronology of colonial mosques in Malaysia from 1808 to 1938. The figure highlighted the 3 case study mosques.

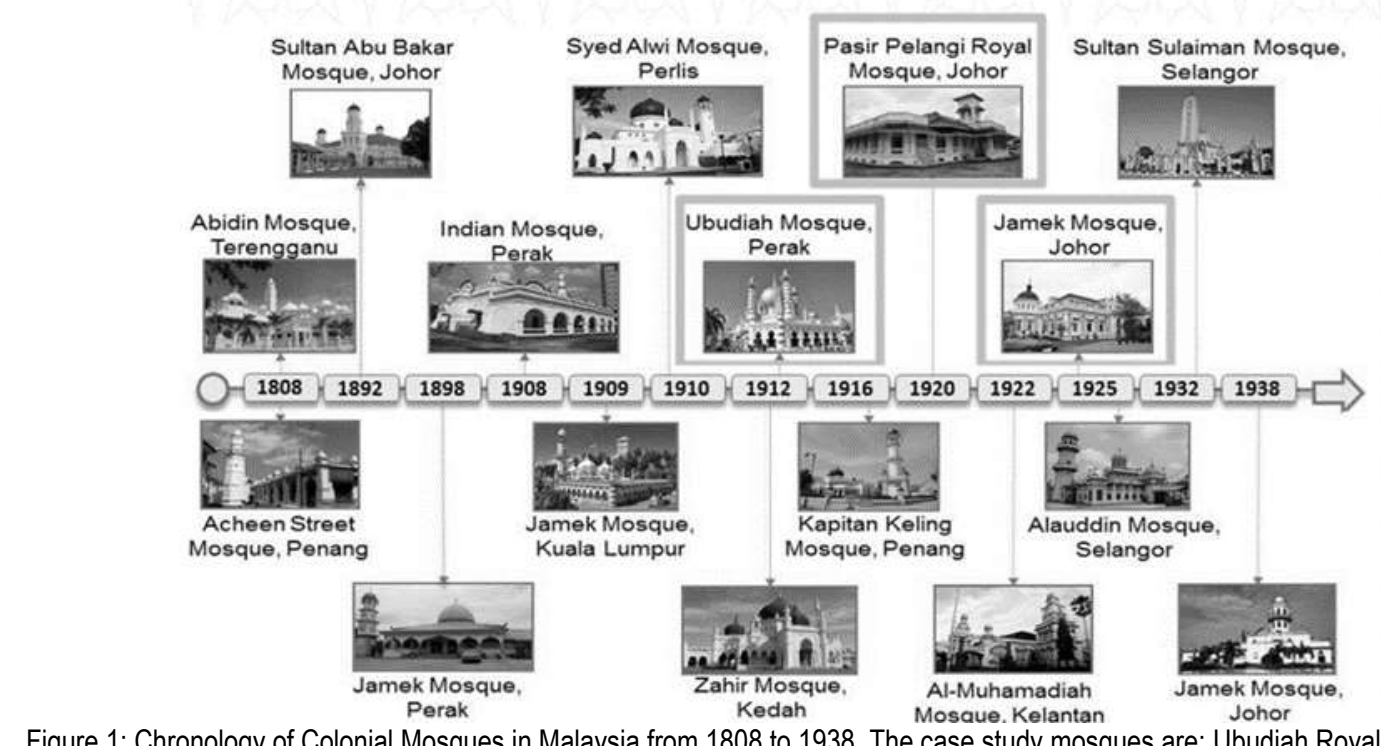

Figure 1: Chronology of Colonial Mosques in Malaysia from 1808 to 1938. The case study mosques are; Ubudiah Royal Mosque (1912), Pasir Pelangi Royal Mosque (1920) and Sultan Ibrahim Jamek Mosque (1925)

(Source: Sanusi et al., 2019)

\subsection{Malaysia Climate}

Malaysia, located near the equator, receives 12 hours of sunlight per day throughout the year, from 7:00 a.m. to 7:00 p.m. The intensity of the solar increases and peaks at 12:00 p.m. until 3:00 p.m. At this hour, the solar radiation is at the maximum level and the sun angle is almost 900 perpendicular to the ground surface. After about 4:00 p.m., the solar intensity decreases back. Figure 2 shows the sun path diagram for Malaysia, which includes hourly solar angles throughout the year. In March, the sun angle is at $90^{\circ}$ from the ground. In June, the sun angle is tilted slightly to the North, while in December, the sun angle tilted slightly to the South (Standards Malaysia, 2014). The East and West solar radiation can be quite intense at about 11:00 a.m. and 4:00 p.m. Therefore, building designers should be aware of the solar angles at the initial stage of the design. Building openings in Malaysia should avoid direct sunlight from the east and west direction and implement a passive daylighting strategy (Arifin \& Denan, 2015).

The direct solar glare can also cause visual discomfort to the indoor environment. Careful consideration of daylight penetration is crucial to maintain visual comfort. Visual comfort is the condition of being free from any distraction, pain, and sensitivity towards visual performance (Nasrollahi \& Shokri, 2016). Diffused lights are part of passive daylighting strategies (Andersen et al., 2013). 


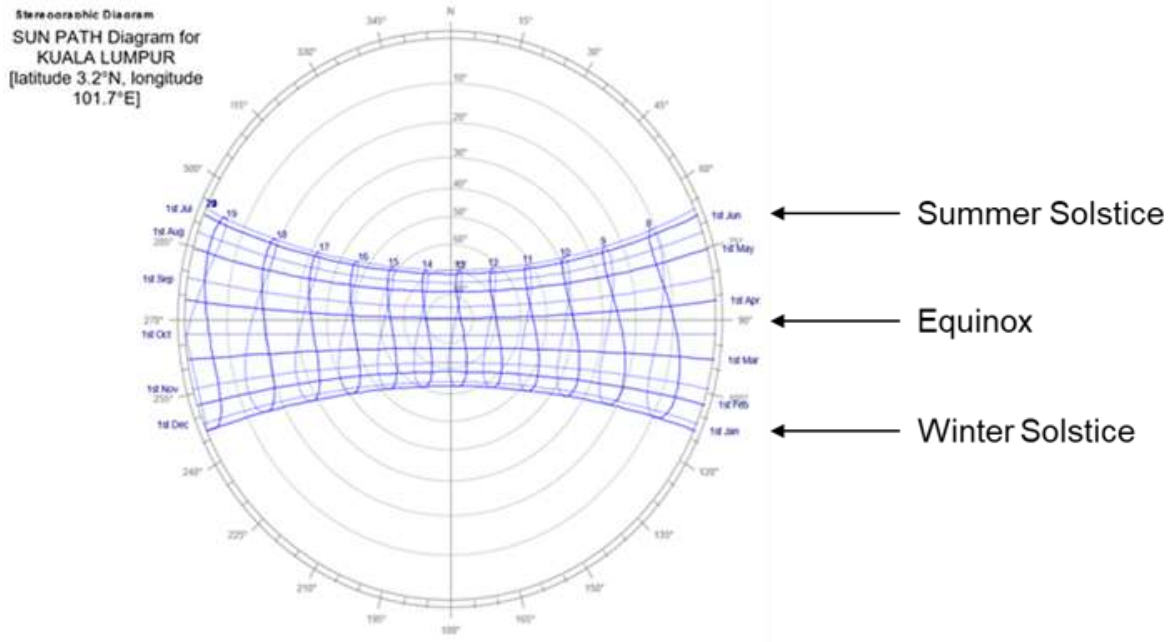

Figure 2: Sun Path diagram for Malaysia, latitude $3.2^{\circ} \mathrm{N}$, longitude $101.7^{\circ} \mathrm{E}$ (Source: Standards Malaysia, 2014)

\subsection{The Principle of Daylight}

Passive daylight strategy is part of passive design strategies, which uses natural resources as the source of energy and operation while reducing energy consumption and operation costs (Womeldorf, 2018). Daylighting is the natural light that illuminates the indoor spaces through openings in the building's skin (Knoop et al., 2020). Furthermore, the windows or openings should be designed to receive the natural daylight and avoid glare at the same time (Standards Malaysia, 2014). Site configuration is also essential to solve the visual discomfort caused by direct sunlight through the building openings. As stated in Standards Malaysia (2014), good building designs are those that responded to the site orientation by having the facades protect the indoor spaces from the direct sunlight from the East and West (Naamandadin et al., 2016). The designer should understand the local solar geometry at the initial stage of design. The landscaping can be part of the passive daylighting strategies. It could reduce the glare, act as shading devices, and shield from excessive solar glare (Standards Malaysia, 2014).

The effectiveness of indoor daylight distribution is identified through its Daylight Factor (DF) measures (Standards Malaysia, 2014). Daylight Factor is measured in percentage; the amount of daylight inside the building can be identified by comparing the total amount of daylight inside with the total daylight at the outside of the building, $D F=$ Eintemal $/ E_{\text {extermal }} \times 100 \%$ (BRE, 1986). Table 1 shows that the acceptable DF ranges from 1.0\% to 3.5\%, with acceptable glare and thermal comfort (Standards Malaysia, 2014).

Table 1: The impact of each Daylight Factor (DF) range

\begin{tabular}{|l|l|l|l|}
\hline DF (\%) & Lighting & Glare & Thermal Comfort \\
\hline$>6.0$ & Intolerable & Intolerable & Uncomfortable \\
\hline $3.5-6.0$ & Tolerable & Uncomfortable & Tolerable \\
\hline $1.0-3.5$ & Acceptable & Acceptable & Acceptable \\
\hline$<1.0$ & Perceptible & Imperceptible & Acceptable \\
\hline
\end{tabular}

(Source: Standards Malaysia, 2014)

Another daylight measures used to ensure visual comfort is Spatial Daylight Autonomy (sDA). SDA is described as the parameters to predict the percentage of space getting specific natural daylight (for example 300 lux) from the range $0 \%$ to $100 \%$. For 300 lux, the percentage of $\mathrm{sDA}$ recorded $>55 \%$ is acceptable and $>75 \%$ is preferred for daylighting (Ayoub, 2020).

Daylight Rule of Thumb (DRT) is used to predict the depth of daylit zones of the space from the window. The daylit zone depth (D) to window height $(H)$ ratio is $D=2 H$ (Figure 3). From this DRT, the higher the window the deeper the daylit zone will be achieved.

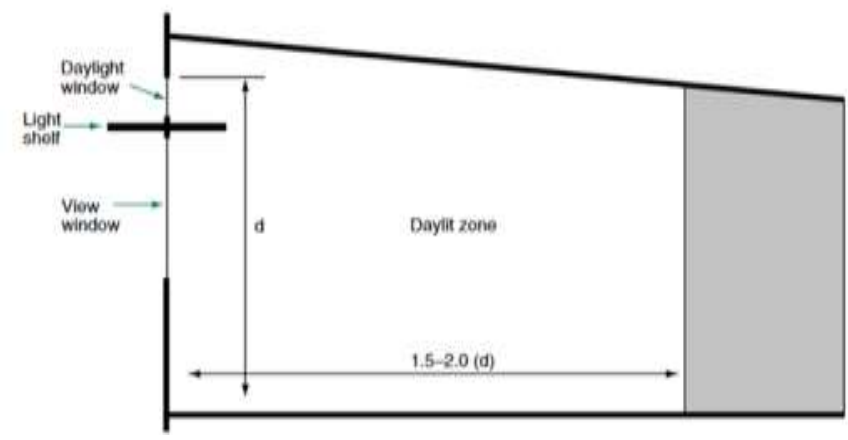

Figure 3: Daylight Rule of Thumb; depth (D) of daylight penetration in relation to the window height $(H)$, Depth $=2 H$. (Source: U.S. Environmental Protection Agency \& U.S Department of Energy) 


\subsection{Methodology}

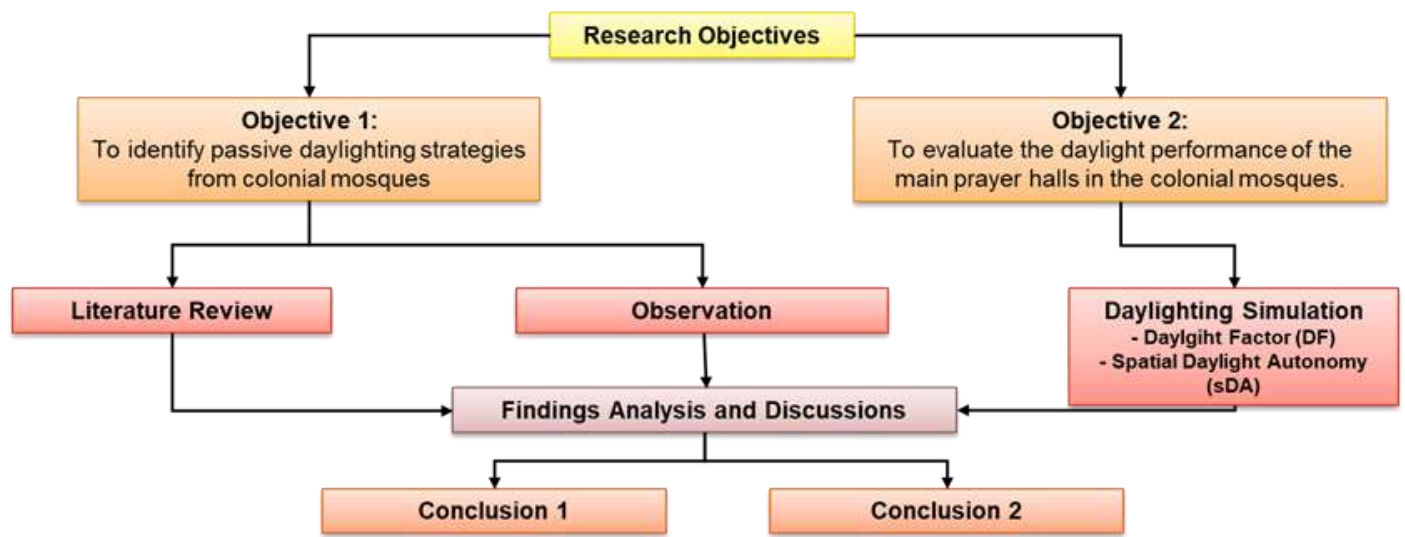

Figure 4: Research Methodology Chart

The research methodology consists of both qualitative and quantitative methods. It consists of Literature Review, Observation, and Daylight Simulation (Figure 4).

\subsection{Literature Review}

A literature review is used in this study to identify the sufficient daylighting level for a mosque in Malaysia. Furthermore, the literature review was carried out to determine the passive daylight strategies applied in mosques from the findings of other research works conducted previously.

\subsection{Observation}

Observations were carried out on the three case studies through site visits and desk research. The findings are presented in Table 2.

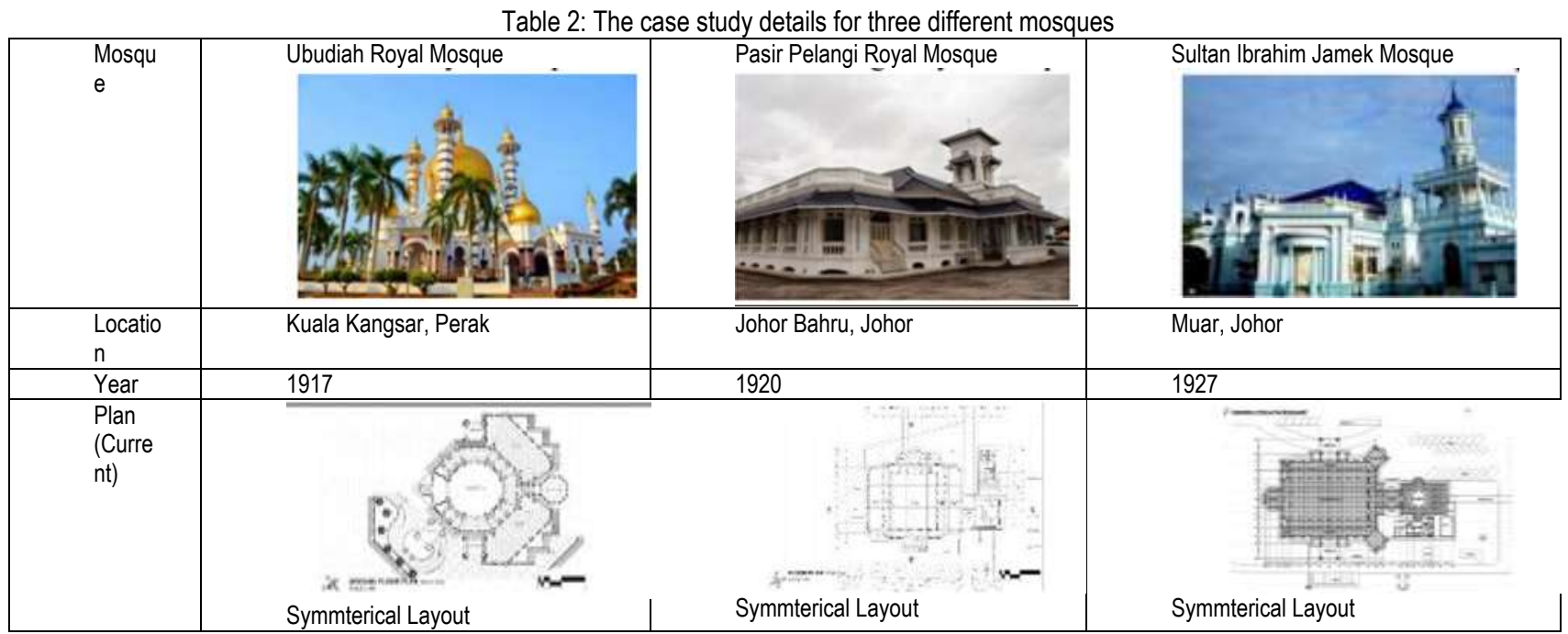

\subsection{Daylighting Computer Simulation}

The Daylight Environmental Simulation was carried out in Simulation Software Sefaira. The three case studies were modeled in Sefaira with appropriate environment settings (Table 3) The virtual model is used for daylighting simulation to identify the building daylight performance, only limited to Daylight Factor (DF) and Spatial Daylight Autonomy (sDA); all the input considerations have been complied with as required by Sefaira software to simulate the daylighting analysis. 
Table 3: Virtual Model of the case study mosques in Daylight Simulation Software, Sefaira.

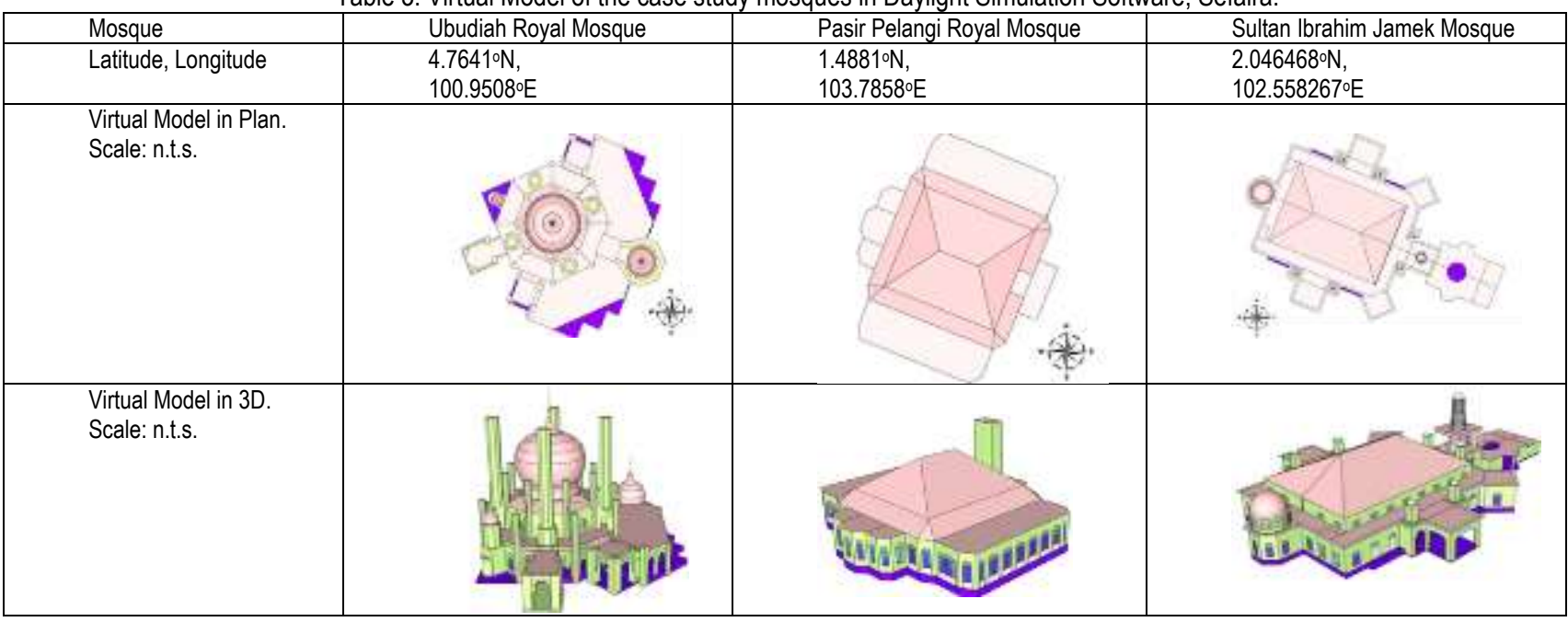

\subsection{Findings}

4.1 Findings on Passive Daylight Strategies in Mosques from Literature Review

Large openings are one of the passive design strategies of Colonial Mosques in Malaysia. It provides good daylighting as well as ventilation (Sanusi et al., 2019). Large openings or glass panels are installed to allow natural lighting, the arrangement of the windows vertically and horizontally could help maximize the daylighting in the mosque (Baharudin \& Ismail, 2014).

In 2017, Arel \& Öner conducted a study on daylight in three historical mosques; Selimiye Mosque in Turkey (Figure 4), Great Mosque of Cordoba in Spain, and Sheikh Lotfollah Mosque in Iran. The study concluded that lights play a role in mosques design, which connects the worshipers to God. However, in Selimiye Mosque, the openings in the dome provide the same illumination level in every corner of a huge space (Arel \& Öner, 2017). Dome could act as part of daylighting strategies for the mosque with a ring of windows at the bottom of the dome (Aljofi, 2018).

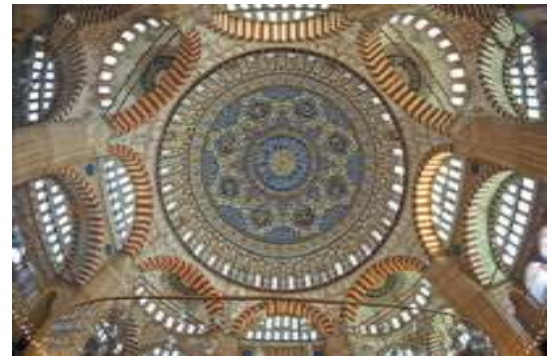

Figure 4: Windows placed around the dome of Selimiye Mosque, Turkey

(Source: Arel \& Öner, 2017)

El-Darwish, \& El- Gendy (2016) has evaluated daylight performance on four historical mosques of the 19th century in Alexandria. The study concluded that clerestory window in mosque design is essential in providing daylight into the main prayer hall. The higher the clerestory window, the higher chance the daylight has penetrated the space (El-Darwish, \& El-Gendy, 2016). The impact of window height relates to the daylight rule of thumb mentioned earlier.

The window to wall ratio is part of the elements that should be considered while designing the opening or windows in the building. The windows should be located above eye level to protect the worshipers from glare while performing their prayers. It can also increase the light distribution inside the mosque (Alabdulazeem et al., 2019).

Some mosques have a verandah, which circulates the main prayer hall. This space acts as overspilled area when it gets crowded. The verandah also protects the main prayer hall from getting unwanted direct sunlight. It is also part of passive daylight strategies in Colonial Mosques (Sanusi et al., 2019). The mosque facade in Malaysia functions to protect the indoor spaces from direct sunlight. The building façade could affect the occupant's visual comfort inside the mosque (Abdullah et al., 2016).

Apart from opening types and design, it was found that bright or white colour surfaces could enhance and reflect the natural daylight into interior building spaces (Belakehal et al., 2016).

The orientation of main prayer hall is determined by the Qiblat direction, which for Malaysia is North-West direction. 


\subsection{Findings on Passive Daylight Strategies in Mosques from Observation}

The observation consisted of spatial orientation and organization of the mosque, the opening properties such as glazing, materials used for the internal surface, and shading devices to avoid visual discomfort. These design considerations observation is referred to according to Malaysian standard MS1525:2014 (Standards Malaysia, 2014)

Table 4: The observation on design consideration for daylighting at the colonial mosques

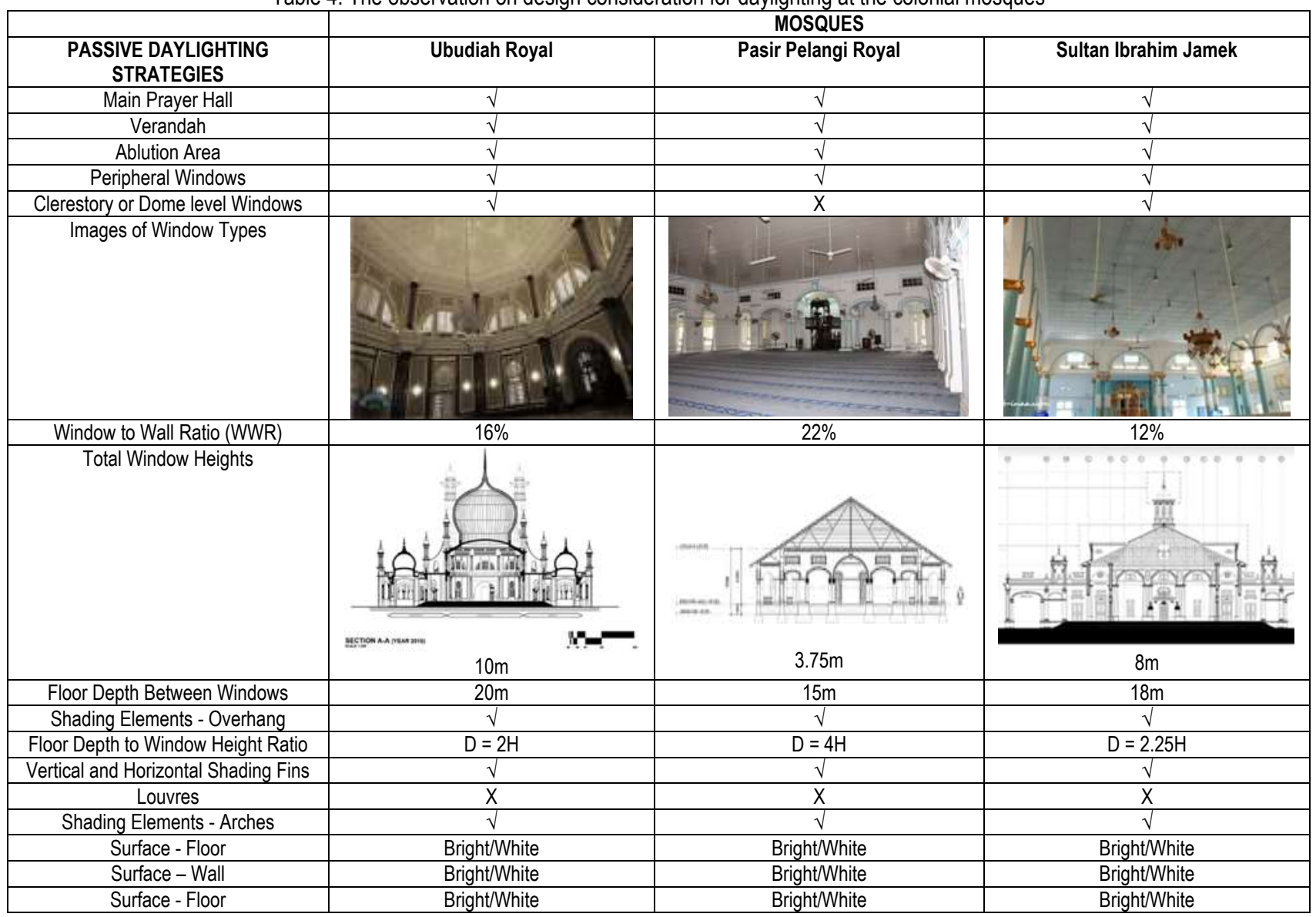

\subsection{Daylight Analysis}

The analysis consisted of Daylight Factor (DF) and Spatial Daylight Autonomy (sDA) analysis. The parameters of the three mosqeus were set up in Sefaira. They are the location of the mosque, the orientation of the mosque, and the minimum illuminance required, which is 300 lux.

Table 5 and Figure 5 show the summary results of the average DF in the main prayer hall of the three mosques. The results show that the DF in the main prayer hall of Ubudiah Royal Mosque is acceptable, while the Daylight Factors (DF) in the other 2 colonial mosques are low, $0.35 \%$.

Table 5: Average DF for the colonial mosques in Malaysia

\begin{tabular}{|c|c|c|c|}
\hline & \multicolumn{2}{|c|}{ Average Daylight Factor (\%) } \\
\hline Mosque & Ubudiah Royal & Pasir Pelangi Royal & Sultan Ibrahim Jamek \\
\hline Main Prayer Hall & $0.90 \%$ & $0.35 \%$ & $0.35 \%$ \\
\hline Verandah & $6.17 \%$ & $3.61 \%$ & $1.53 \%$ \\
\hline Overall & $4.68 \%$ & $2.17 \%$ & $1.76 \%$ \\
\hline
\end{tabular}




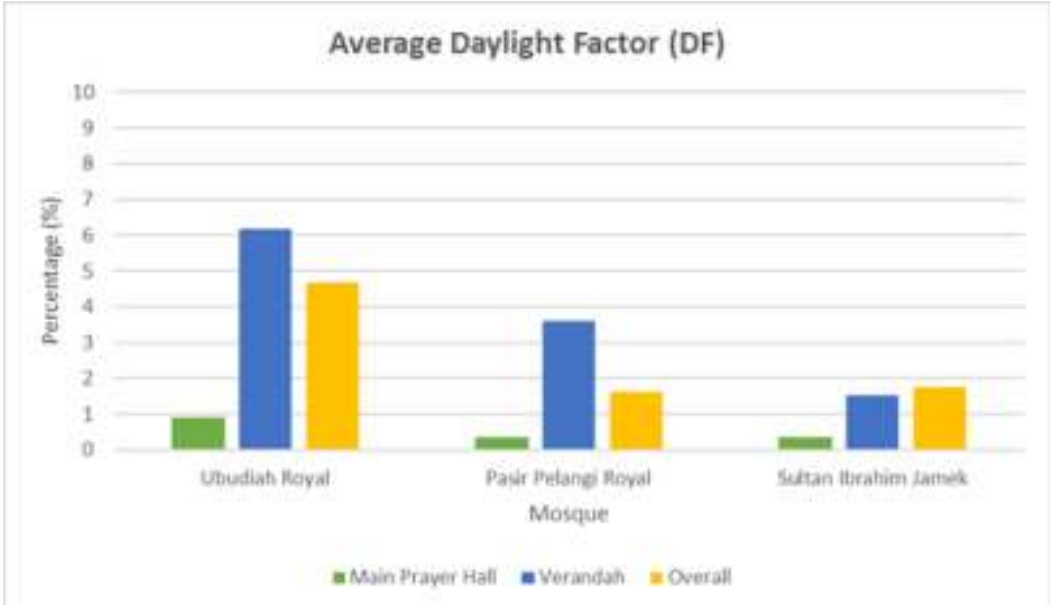

Figure 5: Average DF of the main prayer hall, verandah and overall in the three mosques.

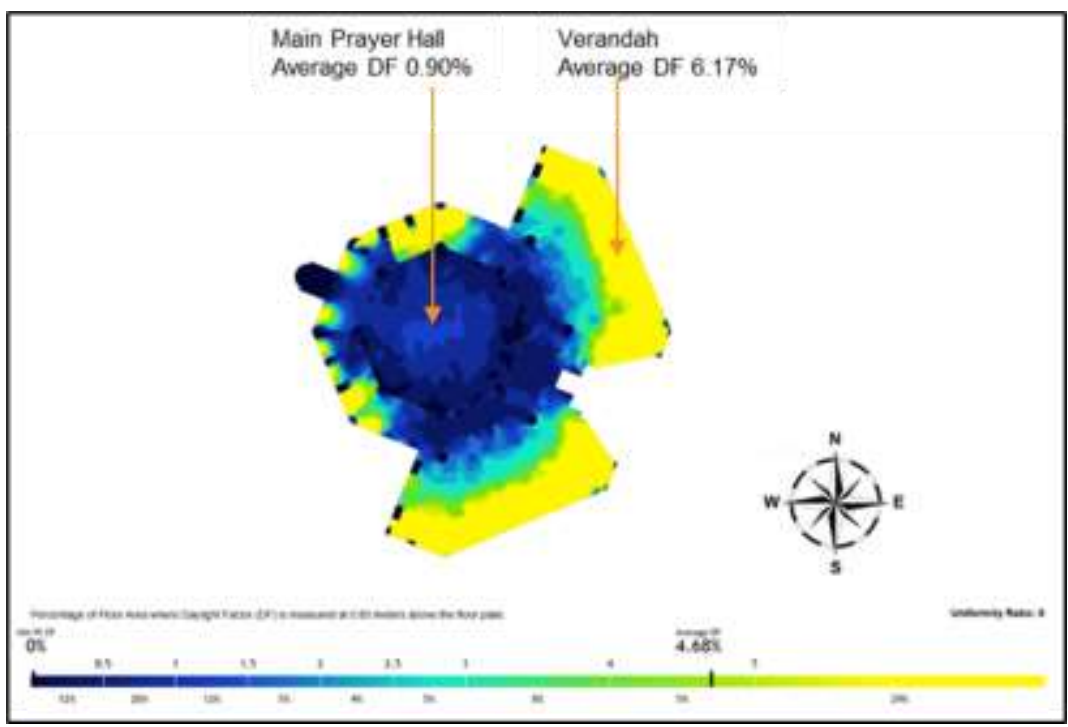

Figure 6: Average DF in Ubudiah Royal Mosque

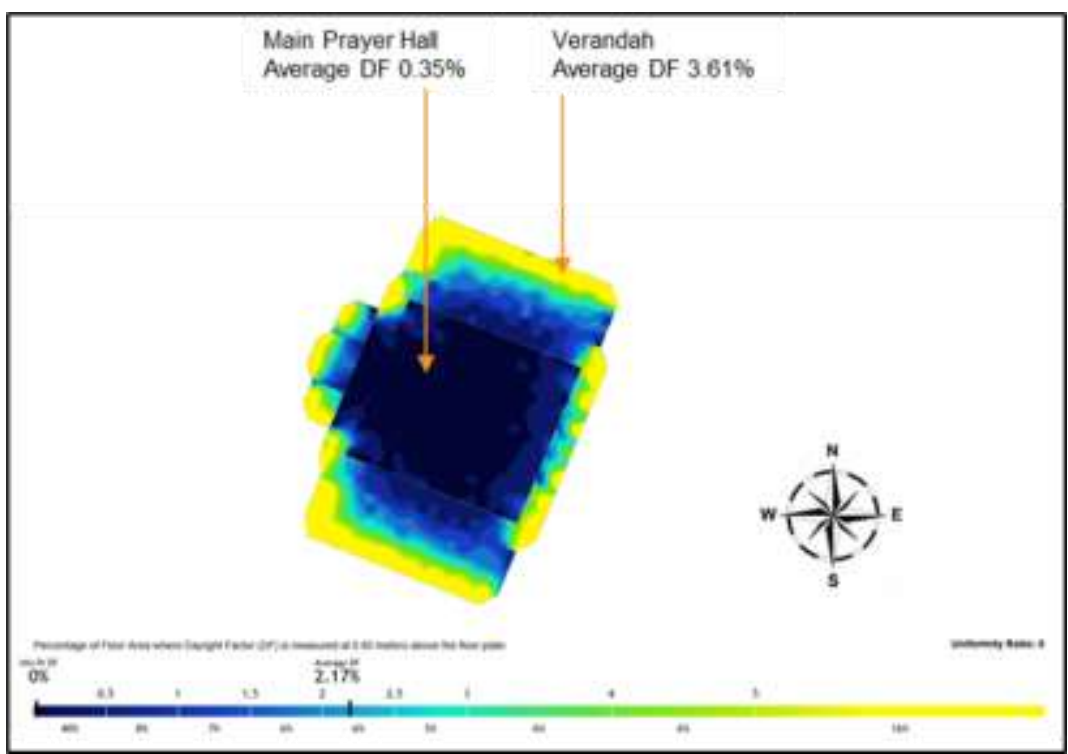

Figure 7: Average DF in Pasir Pelangi Royal Mosque 


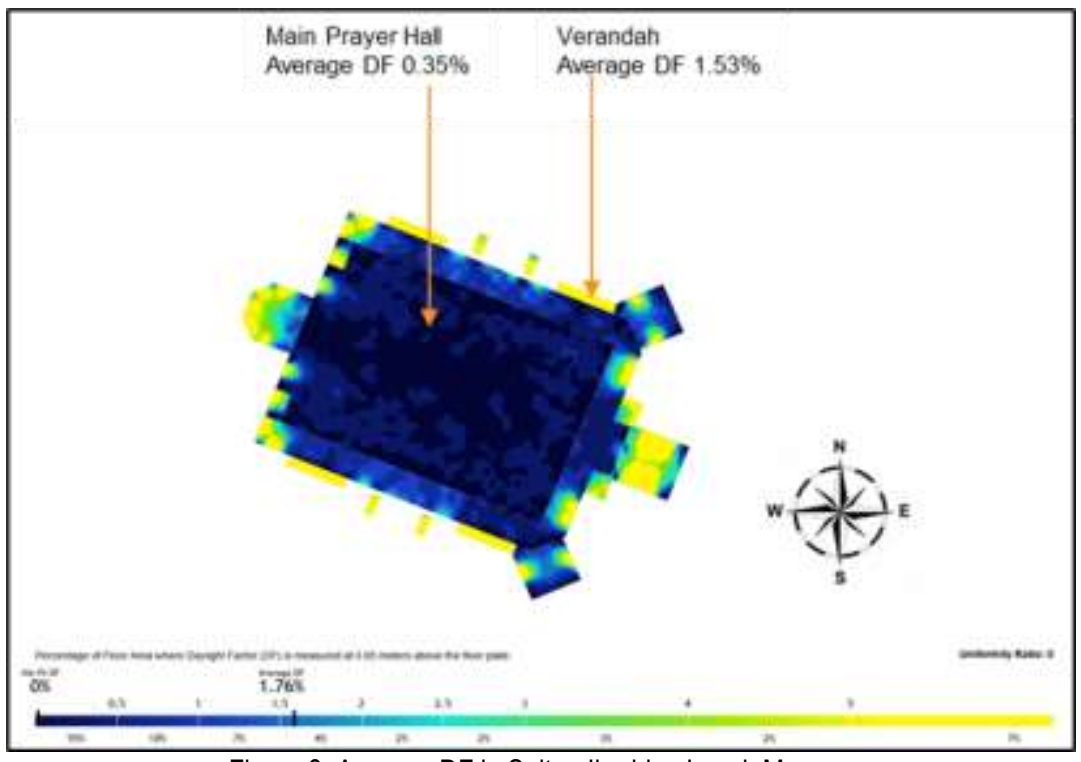

Figure 8: Average DF in Sultan Ibrahim Jamek Mosque

Table 6 and Figure 9 show the summary results of average Spatial Daylight Autonomy (sDA) in the main prayer hall of the three mosques. The results show that the sDA in the main prayer hall of Ubudiah Royal Mosque is acceptable, while the sDA in the other 2 colonial mosques is low.

Table 6: Average sDA for the colonial mosques in Malaysia

\begin{tabular}{|c|c|c|c|}
\hline & \multicolumn{3}{|c|}{ Spatial Daylight Autonomy (\%) } \\
\hline Mosque & Ubudiah Royal & Pasir Pelangi Royal & Sultan Ibrahim Jamek \\
\hline Main Prayer Hall & $61.0 \%$ & $7.0 \%$ & $5.0 \%$ \\
\hline Verandah & $90.0 \%$ & $94.0 \%$ & $69.0 \%$ \\
\hline Overall & $82.0 \%$ & $56.0 \%$ & $32.0 \%$ \\
\hline
\end{tabular}

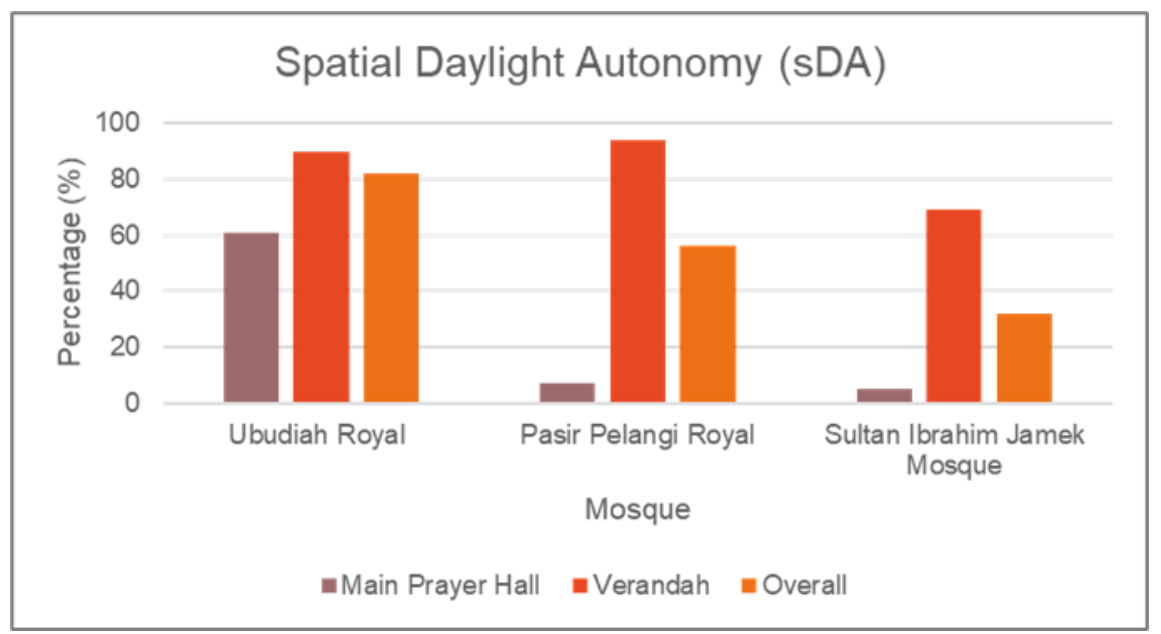

Figure 9: Average sDA of the main prayer hall, verandah and overall in the three mosques. 


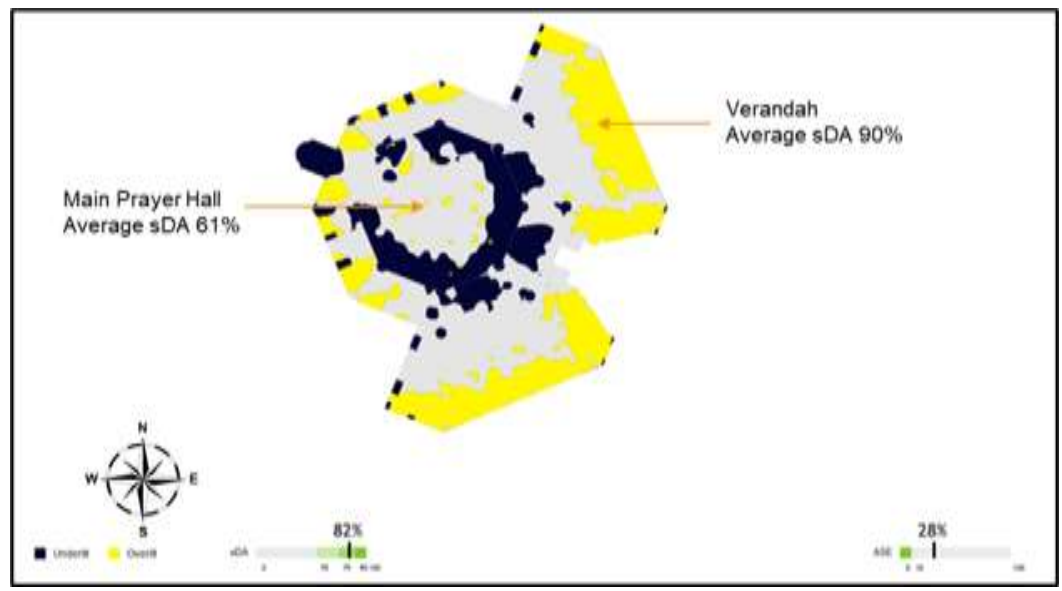

Figure 10: Average sDA in Ubudiah Royal Mosque

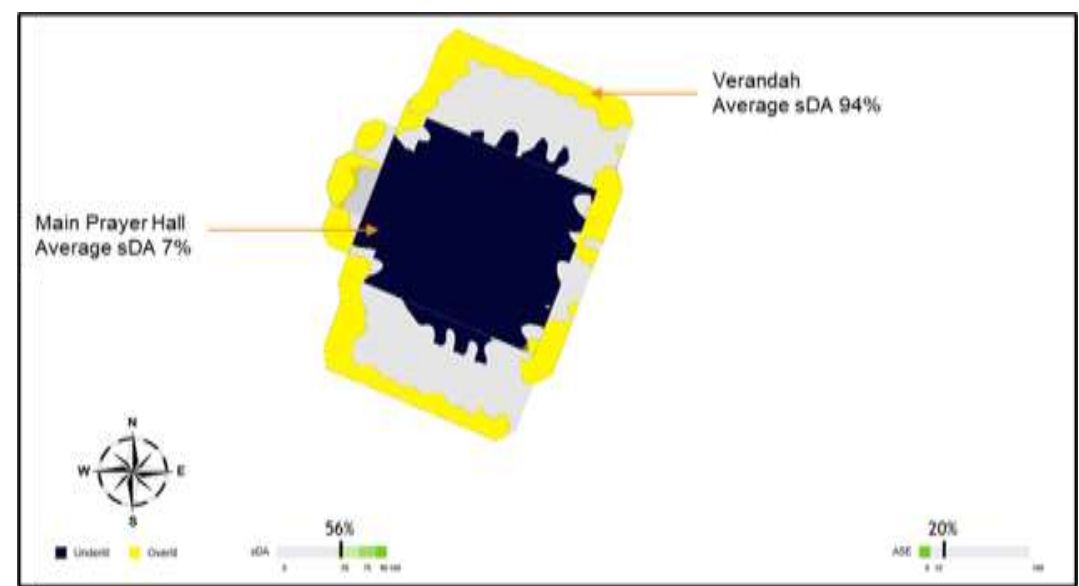

Figure 11: Average sDA in Pasir Pelangi Royal Mosque

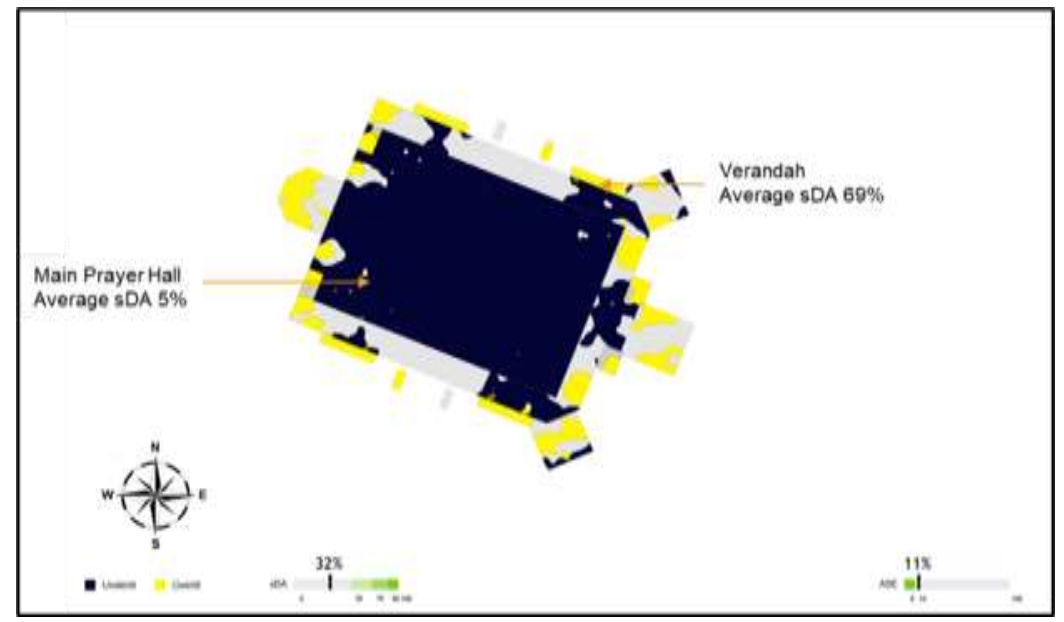

Figure 12: Average sDA in Sultan Ibrahim Jamek Mosque

\subsection{Discussion}

Among the three mosques, only the Average DF of Ubudiah Royal Mosque's main prayer hall is acceptable. Its WWR is $16 \%$, opening height is $10 \mathrm{~m}$ and floor depth from window to window is $20 \mathrm{~m}$. Therefore, Depth (D) of 2 times the Height $(\mathrm{H})$ of the opening, which complies with the Daylight Rule of Thumb in Figure 3. Comparatively, the WWR for Pasir Pelangi Royal Mosque is 22\%, but the window height is low, $3.75 \mathrm{~m}$, and the width from window to window is $15 \mathrm{~m}$, which is deeper. Meanwhile, in Sultan Ibrahim Jamek Mosque, the WWR is $12 \%$, the opening height is $8 \mathrm{~m}$ and the floor depth from window to window is $18 \mathrm{~m}$. Furthermore, Ubudiah Royal Mosque has bigger clerestory windows than the other two Colonial Mosques.

The opening height and floor depth ratio also influence the average sDA. Figure 10 shows acceptable sDA value in the main prayer hall and verandah of Ubudiah Royal Mosque. Comparatively, the other two mosques have very low sDA values. Among the 
three mosques, Ubudiah Royal Mosque has the highest and biggest clerestory windows. Hence, the daylight distribution is better and adequate as compared to the other two mosques.

\subsection{Conclusion and Recommendations}

The first objective was to identify the effective passive daylighting strategies for mosques. The first conclusion is that there are eight passive daylighting strategies to be considered to achieve good daylight in mosques design. They are building form, opening properties, the height of the opening, verandah area, shading elements, windows to wall ratio (WWR), clerestory windows or openings at dome level, and interior surface properties.

The second objective is to evaluate the natural daylighting performance of the main prayer hall in Malaysia's colonial mosques. The second conclusion is that Ubudiah Royal Mosque has an acceptable DF while the other two mosques, Pasir Pelangi Royal mosque, and Sultan Ibrahim Jamek mosque didn't achieve the acceptable range of DF. The placement and design of the windows at the main prayer hall helps in enhancing the daylighting inside the mosque. Due to many openings with the series of arches at the verandah areas, the verandah area recorded more daylighting as compare to the main prayer hall. However, the large clerestory window provides adequate Daylight Factor DF and Spatial Daylight Autonomy sDA value for Ubudiah Royal Mosque.

For future study, it is recommended to extend the study of the passive daylight with various designs of clerestory windows on different roof types, such as the tiered roof. It is also recommended to study further the effect of various glass window materials, such as translucent or stained glass.

\section{Acknowledgements}

We are grateful to IIUM Architecture Department Heritage Lab for providing information on the three colonial mosques case studies. We are also thankful to the administrators of the three Colonial Mosques for giving information on the three mosques.

\section{Paper Contribution to Related Field of Study}

This study will contribute to the knowledge of building facade design, in particular mosques facade design. The findings from this study have shown the impact and benefits of openings in allowing passive daylight into indoor spaces.

\section{References}

A Ghafar Ahmad. (1999). The Architectural Styles of Mosques in Malaysia: In The Architectural Styles Of Mosques in Malaysia: From Vernacular to Modern Structures (Issue Proceedings of the Symposium on Mosque Architecture: The Historic and Urban Developments of Mosque Architecture, King Saud University, Riyadh, Saudi Arabia, Vol. 2, pp. 147-163.

Al-Ashwal, N. T., \& Hassan, A. S. (2017). The integration of daylighting with artificial lighting to enhance building energy performance. AIP Conference Proceedings, 1892..

Alabdulazeem, A., Bat'hi, A. Al, Ba'adi, R. Al, \& Malick, F. H. (2019). Appropriate Daylighting Sources Design For Spiritual Spaces In Saudi Arabia. Mosque Architecture: Present Issues and Future Ideas, 1, 503-521.

Aljofi, E. K. (2018). The Potentiality of Domes on Provision of Daylight in Mosques. International Journal of Applied Engineering Research, $13(7), 5103-5112$.

Andersen, M., Gagne, J. M. L., \& Kleindienst, S. (2013). Interactive expert support for early stage full-year daylighting design: A user's perspective on Lightsolve. Automation in Construction, 35, 338-352.

Arel H.S., \& Öner M. (2017). Use of Daylight in Mosques: Meaning and Practice in Three Different Cases. International Journal of Heritage Architecture, 1(3), $421-429$.

Arifin, N. A., \& Denan, Z. (2015). An Analysis of Indoor Air Temperature and Relative Humidity in Office Room with Various External Shading Devices in Malaysia. Procedia - Social and Behavioral Sciences, 179, 290-296

Ayoub, M. (2020). A review on machine learning algorithms to predict daylighting inside buildings. Solar Energy, Vol. 202, 249-275.

Baharudin, N. 'Athiqah, \& Ismail, A. S. (2014). Communal Mosques: Design Functionality towards the Development of Sustainability for Community. Procedia - Social and Behavioral Sciences, 153(October 2014), 106-120.

Belakehal, A., Tabet Aoul, K., \& Farhi, A. (2016). Daylight as a Design Strategy in the Ottoman Mosques of Tunisia and Algeria. International Journal of Architectural Heritage, 10(6), 688-703.

BRE. (1986). Estimating Daylight in Buildings: An Aid to Energy Efficiency, Part 2 (Issue pt. 2). BRE.

El-Darwish I.I., \& El- Gendy R.A. (2016). The role of fenestration in promoting daylightperformance. The mosques of Alexandria since the19th century. Alexandria Engineering Journal, 55, 3185-3193.

Heschong, L., Wright, R. L., \& Okura, S. (2002). Daylighting impacts on human performance in school. Journal of the Illuminating Engineering Society, 31(2), 101-114 
Lo Verso, V. R. M., \& Pellegrino, A. (2019). Energy saving generated through automatic lighting control systems according to the estimation method of the standard EN 15193-1. Journal of Daylighting, 6(2), 131-147

Rosniza, Othman (2011) Mihrab design and ornamentation of selected mosques in Malaysia / Rosniza Othman. PhD thesis, Universiti Malaya.

Sanusi, A. N. Z., Abdullah, F., Azmin, A. K., and Kassim, M. H. (2019). Passive Design Strategies of Colonial Mosques in Malaysia. Green Building and Renewable Energy. Med Green Forum 2019 - Part of World Renewable Energy Congress and Network. Springer.

Shah, M. A., Arbi, E., \& Inangda, N. (2014). Transformation of Mosque Architecture in Malaysia: Proceeding of the International Conference on Arabic Studies and Islamic

Civilization ICasic 2014, 2014(March), 54-64.

Standards Malaysia. (2014). Energy efficiency and use of renewable energy for non -residential buildings - Code of practice (Second revision). Malaysian Standard MS $1525: 2014,2,1-61$

U.S. Environmental Protection Agency and U.S. Department of Energy (2003). Daylighting in Laborataries. In: Laboratories For The 21st Century: Best Practices.

Womeldorf, W. A. (2018). Pasive Design Strategies in Architecture. Design Strategies in Architecture, 1-9. 